\title{
Habitat distribution of myriapods (Chilopoda, Diplopoda) in the town of Shumen and the Shumen Plateau (NE Bulgaria)
}

\author{
Распределение местообитаний многоножек (Chilopoda, \\ Diplopoda) в городе Шумен и на Шуменском плато \\ (северо-восточная Болгария)
}

\author{
D. Bachvarova ${ }^{1}$, A. Doychinov ${ }^{1}$, Ch. Deltchev ${ }^{2}$, P. Stoev ${ }^{2}$ \\ А. Бъчварова ${ }^{1}$, А. Аойчинов ${ }^{1}$, Х. Аелчев ${ }^{2}$, П. Стоев ${ }^{2}$
}

\footnotetext{
${ }^{1}$ Konstantin Preslavsky University of Shumen, 115, Universitetska Str., 9700 Shumen, Bulgaria.

${ }^{1}$ Шуменски университет “Епископ Константин Преславски”, ул. Университетска 115, Шумен, 9712 България.

${ }^{2}$ National Museum of Natural History, 1, Tsar Osvoboditel Blvd, 1000 Sofia, Bulgaria.

${ }^{2}$ Национален природонаучен музей БАН, бул. Цар Освободител 1, София, 1000 България.
}

KEY WORDS: millipedes, centipedes, urban, rural, communities, Shumen, Shumen Plateau, NE Bulgaria.

КЛЮЧЕВЫЕ СЛОВА: millipedes, centipedes, urban, rural, съобщества, Шумен, Шуменско плато, Североизточна България.

ABSTRACT. The present paper provides the first comparative analysis of the community composition and habitat distribution of myriapods (Chilopoda, Diplopoda) in the urban, suburban and rural habitats of the town of Shumen and Shumen Plateau. For both studied classes, Chilopoda and Diplopoda, the green areas of the city center are the species poorest, with Geophilomorpha and Scolopendromorpha being apparently most influenced by the anthropogenic pressure. The highest species diversity has been established in the suburban area with a total of 37 species 20 centipedes and 17 millipedes, which accounts for $64 \%$ of the 58 species known in the region. According to the index of persistence (invariably) of Tischler the degree of attachment of centipedes to a particular habitat is less than that of millipedes, which are trophicaly dependent on surrounding vegetation. The highest degree of similarity in myriapod communities in the studied habitats is reported between Park Kyoshkovete and reserve Bukaka where the Czekanowski-Dice-Sörensen (Qs) index is 0.83 for centipede and 0.81 for millipede communities. No alien species have so far been found in the fauna of Shumen, which is unusual given the size of the city, its long history, established trade relations with other regions since antiquity and the active transportation of products from and to different parts of the world.

РЕЗЮМЕ. Настоящая статья представляет первый сравнительный анализ видового состава растительных сообществ и биотопического распределения многоножек (Chilopoda, Diplopoda) в городских, пригородных и природных местообитаниях в регионе города Шумен и плато Шумен. Самыми бедными по составу в обоих исследованных класcax Chilopoda и Diplopoda являются парковые зоны в центре города, а наиболее пострадавшими от антропогенного воздействия - очевидно, Geophilomorpha и Scolopendromorpha. Наибольшим видовым разнообразием отличается пригородная зона, где находятся 37 видов - 20 хилоподы и 17 диплоподы, что составляет $64 \%$ известных 58 видов в этом районе. Согласно индексу устойчивости (постоянства) Tischler (C), степень привязанности к конкретной среде обитания Chilopoda меньше, чем y Diplopoda (многоножки класса Diplopoda являются трофически зависимыми от состава растительных формаций). В исследованных местообитаниях наиболее высокая степень сходства сообществ многоножек установлена при сопоставлении парка Kioshkovete и заповедника Bukaka, для которых индекс сходства по Czekanowski-Dice-Sörensen (Qs) составило 0,83 для Chilipoda и 0,81 для Diplopoda. В фауне Шумена не обнаружено чужеродных видов, что является необычным, учитывая масштабы города, его долгую историю, установленные торговые отношения с другими регионами в древности и активную транспортировку продуктов в разные регионы мира из них.

\section{Introduction}

The island isolation and fragmentation of the urban habitats, as well as the increased anthropogenic impact cause the formation of specific faunal complexes and the emergence of new species communities, quite different from those in natural habitats. Comprehensive study of urban and rural species communities could help understand the strength and level of distortion of the human activity. In recent decades, the species composition of Myriapoda in urban and suburban areas has been the subject of studies by many researchers. Eng- 


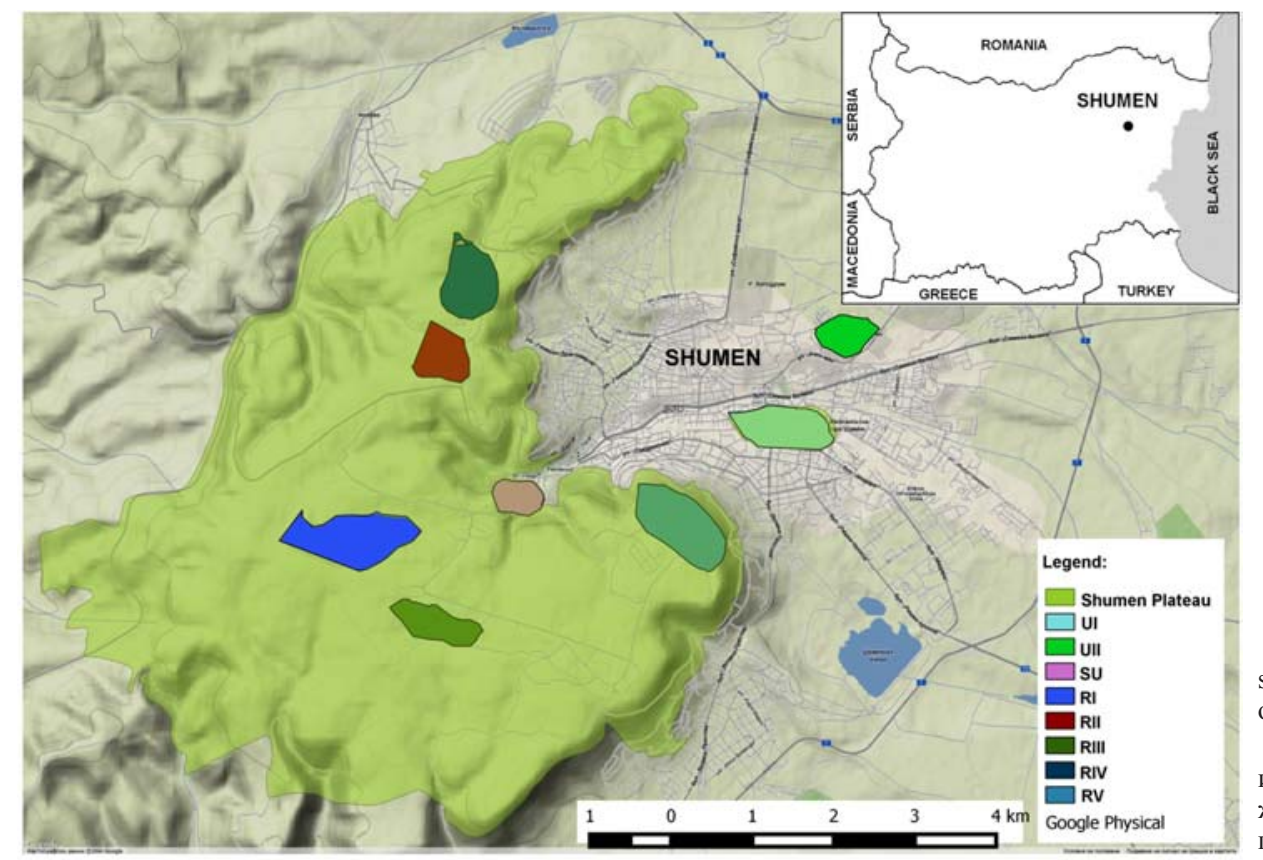

Fig. 1. Map of the research area with the location of the sampling sites.

Рис. 1. Карта района исследования с местоположением участков отбора проб.

hoff [1973] provides a list of the centipedes occurring in the city greens of Copenhagen, Davis [1979] makes similar analysis for the species in London. Andersson [1983] explores the centipedes of Göteborg, and Zapparoli [1992] provided a very detailed list of centipedes found in the city of Rome. Centipedes from urban areas are described in the papers on the biological characteristics of soils in Bonn-Bad Godesberg, Germany [Frund, 1989; Schulte et al., 1989]. In a study of the urban environment in Vienna Kuhnelt [1989] also reported several species. Leśniewska [1996] studied centipedes communities in Poznan, and in a study of the myriapod fauna of Sofia Stoev [2004] reported 21 species recorded in a highly urbanized environment. A similar study of the fauna in the city of Skopje was published by Gorgievska et al. [2008]. Studies of Wytwer [1995] on the similarities and fauna connections in the centipede communities in Mazowia forests and urban green areas in Warsaw support the view that the question of the formation and evolution of the species diversity in communities living in urban greens are more significant in regard to the study of the circumstances and conditions leading to the evolution of the natural fauna [Trojan, 1994].

Despite the great diversity, urban habitats have one common feature - they are subjected to different types and degrees of anthropogenic impact and high fragmentation of habitats. Therefore, in different parts of the city one can observe different degrees of changes in the environmental conditions that form an urban-rural axis from highly urbanized central, through less altered suburban zones to natural rural habitats [McDonnell et al., 1993, 1996; Pouyat et al., 1994, 1995]. The higher anthropogenic pressure leads to exhaustion and impoverishment of the fauna [Chudzicka, Skibinska, 1998a, $1998 \mathrm{~b}]$, manifested through reduced number of species
[Vepsäläinen, Wuorenrinne, 1978; Czechowski, 1982; Kasprzak, 1981; Niedbala et al., 1982; Pisarski, 1982; Skibinska, 1978, 1982, 1986; Sawoniewicz, 1982, 1986; Winiarska, 1986; Wytwer, 1995]. The fauna impoverishment often follows the gradient of increasing anthropogenic impacts towards the city center. Another characteristic of urban fauna is the presence of species of foreign origin, which generally adapt better to anthropogenically influenced habitats, rather than to areas that have not been exposed to human pressure.

At this point in Shumen and the Shumen Plateau there are a total of 58 known species of myriapods 21 species of class Diplopoda and 37 species of class Chilopoda [Bachvarova, 2011].

The purpose of this study is to investigate the distribution of myriapods across habitats and to offer a comparative analysis of the complexes of species in the natural habitats of the Shumen Plateau, the metropolitan area and urban green areas of Shumen.

\section{Material and methods}

\section{Study area.}

The material has been collected from 8 sites, distinguished by their location, composition of plant formations and level of anthropogenic pressure. Two of them are located in heavily urbanized area which is subject to considerable human pressure: UI - City park and UII - University of Shumen park. The third site SU Kyoshkovete Park, is located in a transitional zone between urban and rural areas. Collecting sites 4-8 are situated in rural habitats located in the Natural Park Shumen Plateau: RI — beech forest at Bukaka reserve, RII - mixed deciduous-coniferous forest, RIII hornbeam forest, RIV — pine forest and RV — Open meadow (Fig. 1). 


\section{Characterization and floristic analysis of the ec- osystems at the sampling sites.}

The Nature park Shumen Plateau is located in the southeastern suburbs of the Moesian plane. The park falls within Moesian beech forest and the Lower planehilly oak forest belts with an altitude from 0 to $800 \mathrm{~m}$ [Andreev, 1992]. In general, the vegetation cover is characterized by the predominance of xerophylic and more or less thermophilic elements, such as Carpinus orientalis Mill, Quercus pubescens Willd., 1796, Q. cerris L., 1753, Q. frainetto Ten. (1813), Syringa vulgaris L., 1753, Paliurus spina-christi Mill. The mesophilic and mesothermic elements, such as Carpinus betulus L., 1753, Quercus robur L., 1753, Tilia tomentosa Moench, Ulmus campestris L., have more limited distribution. Pretty close to the mesophilic ecosystems are those of the Moesian beech Fagus sylvatica L. ssp. moesiaca (K. Malý) Hjelmquist, but they must be regarded as intermediate to the xerophylic ones. The coniferous forests cover about $16 \%$ of park's territory and are composed of artificially introduced tree species. The chasmophytic communities within the protected area relate to the endemic for the Balkan Peninsula union Ramondion nathaliae, that combines rock phytocenoses of limestone substrates. The average altitude is $350 \mathrm{~m}$, with the highest point being 502 $\mathrm{m}$ and the lowest $-225 \mathrm{~m}$.

\section{Site description.}

RI: Theromophilic Moesian beech forest [Tzonev et al., 2006], with presence also of Carpinus betulus L., 1753, Quercus dalechampii Ten., Quercus frainetto Ten. (1813), Quercus cerris L., 1753, Tilia tomentosa Moench, etc. Scrub floor does not form almost anywhere. The participation of several types of xerophilic species from the neighboring oak and hornbeam forests, such as Glechoma hederacea L., Hedera helix L., 1753, Lathyrus laxiflorus (Desf.), Melissa officinalis L., 1753, Mercurialis perennis L., Milium effusum L., Muscari botryoides Mill, Polygonatum latifolium (Jacq.) Desf., Ruscus aculeatus L., 1753, Tamus communis (L.), 1753, Viola riviniana Rchb., etc. Dominants for the grass synusia are Rubus hirtus Waldst. \& Kit., Poa nemoralis L., Brachypodium sylvaticum (Huds.) Beauv., Galium odoratum (L.) Scop., 1771, Festuca heterophylla Lam., Lamiastrum galeobdolon (L.) Ehrend. \& Polatschek, Sanicula europaea L., 1753, Cyclamen coum Mill and Carex sylvatica Huds. Category according to EUNIS habitat classification: G1.661. Geographical coordinates: N 43ำ $15.592^{\prime}$; E 26 $6^{\circ} 3.310^{\prime}$. The $\mathrm{pH}$ of soil is 4.18 .

RII: Located at the border of coniferous and deciduous hornbeam-Sessile oak forests. In a relatively equal amount are found the following tree species: Fagus sylvatica L., 1753, C. betulus, Pinus nigra J.F.Arnold, 1785, and Pinus sylvestris (L., 1758). The scrub floor resembles that of the coniferous forests and includes representatives of Rosa sp., Crataegus monogyna Jacq., 1775, P. spina-christi and not as often of Fraxinus ornus L., 1753. Grass synusia is composed primarily by xerophytic species, such as $H$. helix, $M$. botryoides, $G$. hederacea, $V$. riviniana, etc. Category according to EUNIS habitat classification: G3.F12+G1.A32+G1.6. Geographical coordinates: N 43⒗502'; E 26 ${ }^{\circ} 53.376^{\prime}$. The $\mathrm{pH}$ of soil is 5.16 .

RIII: Besides the dominant species $C$. betulus and Quercus petraea (Matt.) Liebl., 1784 in the composition of the tree floor there are also $F$. sylvatica, $C$. orientalis, $Q$. frainetto, $Q$. cerris and Populus tremula L., 1753. The scrub synusia is composed of C. monogyna and Corylus avellana L. (1753) and less often of $F$. ornus. Except for Lamiastrum galeobdolon (L.) Ehrend. \& Polatschek, the other major dominants among the grasses are $P$. nemoralis, $B$. sylvaticum, $F$. heterophylla and Melica uniflora Retz.. Category according to EUNIS habitat classification: G1.A322. Geographical coordinates: $\mathrm{N} 43^{\circ} 14.605^{\prime}$; E $26^{\circ} 54.618^{\prime}$. The $\mathrm{pH}$ of soil is 5.02 .

RIV: This sampling site is located in a coniferous forest, which is composed mainly of a pure culture of $P$. nigra. The coniferous forests in the Shumen Plateau occupy about $16 \%$ of its territory and are composed of artificially introduced tree species. The scrub floor is composed of Rosa sp., C. monogyna, and not as often of Prunus spinosa L. Category according to EUNIS habitat classification: G3.F12. Geographical coordinates: N $43^{\circ} 16.791^{\prime}$; E $26^{\circ} 53.562^{\prime}$. The $\mathrm{pH}$ of soil is 7.19 .

RV: Depending on its phytocoenological outlook, the site can be divided into two parts. Its eastern half belongs to the xerophytic grasslands, which on the territory of the Shumen Plateau refer to the phytocoenose Festuco-Brometea. These phytocoenoses occur at places where forests have been destroyed in the distant past. Now they compose only a minor part of the plant cover in the Nature park $(0.6 \%)$. The western part of site is occupied by low shrub phytocoenoses of the Prunetum tenellae association, which have only a symbolic participation $(0.08 \%)$ in the vegetation cover of the Shumen plateau. These secondary communities are found on eroded landscapes along with $S$. vulgaris, $P$. spina-christi, P. spinosa, C. orientalis and xerophilic grasslands. Category according to EUNIS habitat classification: E1.2. Geographical coordinates: N $43^{\circ} 15.504^{\prime}$; E $26^{\circ} 55.599^{\prime}$. The pH of soil is 7.76 .

SU: The site is located in semi-natural formation, strongly influenced by the human activity. There are no dominant species, although horse chestnut, Aesculus hippocastanum Linnaeus, 1753, is quite common. Well represented are also: T. tomentosa, Acer campestre L., Acer and Juglans regia L., (1753). Scrub floor is very scanty and represented by ornamental species, such as $H$. helix. In the grass synusia there are representatives of Parietaria officinalis L., 1753, Dactylis glomerata L., 1753, Geum urbanum L., Geranium sp., Ballota nigra L., Vinca minor L., Chaerophyllum temulentum L., etc. Geographical coordinates: N 43ำ $15.927^{\prime}$; E $26^{\circ}$ $54.028^{\prime}$. The $\mathrm{pH}$ of soil is 7.41 .

UI: Wet meadows in highly urbanized spaces small parks, public squares and around the streets. 
There are no clearly dominant species. Phytocenoses are represented by $A$. hippocastanum, Amorpha fruticosa L., 1753, Platanus orientalis L., 1753, Prunus mahaleb L., T. tomentosa, A. campestre, Cercis siliquastrum L., Bellis perennis L., Lolium perenne L., Taraxacum officinale F.H. Wigg., P. officinalis, $G$. urbanum, etc. Geographical coordinates: N 43ำ $16.260^{\prime}$; E $26^{\circ} 56.403^{\prime}$. The $\mathrm{pH}$ of soil is 7.59 .

UII: The site is located near the University of Shumen, which is heavily urbanized, with several sport facilities (football playground and two tennis courts), three parking lots, a number of buildings, alleys and lawns. The total surface of the area amounts to 180 ha. In terms of habitats it can be divided into two parts. The northeast part is composed of mixed plantations of park type, where the most numerous spicies are $P$. nigra, T. tomentosa, Robinia pseudoacacia L., A. hippocastanum and $C$. siliquastrum. The scrub floor is relatively scanty and grass sinusius is formed by $H$. helix, Clematis vitalba L. (1753), Salvia nemorosa L., Galium aparine L., Poa pratensis L., C. bursa-pastoris, T. officinale, Malva sylvestris L., Silene vulgaris (Moench), etc. The southwestern part of site encompasses meadows with individual trees and shrubs. Geo-

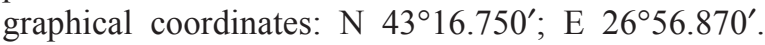
The $\mathrm{pH}$ of soil is 7.37 .

The material was collected by using 10 pitfall traps in each sampling site set in a line, at a distance of 10 meters from each other. Traps were emptied at a monthly basis in the period April 2007 - May 2009. Besides, underground traps aiming to collect the fauna inhabiting only the deep soil strata were used too. Direct sampling, conducted both at the eight workstations and at specific habitats and microhabitats, such as areas inbetween domestic buildings, construction sites, garden path-ways, patios and yards in the city center and more was carried out too. In addition to above methods 4 soil samples amounting to $0.75 \mathrm{~m}^{3}$ were taken from each site in the period June-July 2009 and September-October 2009 and further extracted in laboratory conditions by Tüllgren-Berlese apparatus for 48 hours.

The differences in the habitat distribution of miriapod communities were examined by cluster agglomerative method and by Czekanowski-Dice-Sörensen's similarity index (Qs) with PAST 2.03 program [Hammer et al., 2001]. The degree of attachment of a specific species to a particular habitat has been measured by the index of persistence (invariability) of Tischler (C).

\section{Results}

A total of 5077 millipedes were collected, out of which 3442 were collected by pitfall traps, 1214 by direct sampling (148 of which by underground traps) and 421 individuals by soil samples. Of the 20 species registered in the study, 18 were collected by pitfall traps, 1 species (Trachyspheara costata) - by hand sampling in the Zandana cave, and 1 species (Typhlo- iulus kotelensis) was found only in soil samples taken from Kyoshkovete (Table 1).

The collected centipedesamount to 2756 individuals, 1227 of which were caught using pitfall traps, 811 were hand-picked and 718 through Tüllgren extraction (Table 2). Out of the 33 centipede species registered in the area, twelve species - Scutigera coleoptrata, Eupolybothrus transsylvanicus, Lithobius erythrocephalus, L. mutabilis, L. aff. melanops, $L$. parietum, L. schuleri, L. aff. micropodus, Harpolithobius sp.n. 2, Scolopendra cingulata, Cryptops trisulcatus and Strigamia engadina were collected by pitfall traps and/or direct sampling. Shendyla aff. delicatula, Sh. aff. tyrolensis (= Shendyla aff. montana balcanica (Kaczmarek, 1969) [Bonato, Minelli, 2014]), Sh. aff. walachica, Geophilus flavus and Strigamia transsilvanica, as typical geobionts were found only through extractions of soil lumps. Through direct sampling in the Shumen University park (UII) only three Lithobius microps were caught. However, the results of the soil samples in this area indicate significant presence of the species.

Analysis of the habitat distribution of myriapods in the studied region was made on the basis of the results of the quantitative sampling with pitfall traps. Although only surface-dwelling and active species could be collected, when used for long periods of time, this method provides significant insight to the species composition. The absence of a certain species in the traps does not by far mean that the species is absent in this habitat. It rather indicates that it could be inactive on the ground. Despite all these considerations, the amount of captured individuals and the number of species registered through pitfall traps obviously depends not only on the type of activity, but also on its degree of affluence. Therefore, it is recommended that quantitative studies with pitfall traps, be applied for at a period of one year [Baars, 1979]. In the current case, the duration period was two years, which ensures that the collection of individuals reflects the presence, size and density of the population, as well as the activity of the species.

During the analysis of habitat distribution the results from the direct sampling were not taken into account because the amount of material collected at each site using this method depends on the frequency of attendance of the terrain and the length of the hand collecting. Qualitative samplings have performed with different duration and frequency in the studied areas, so their results are not indicative of the number of species in a particular area. The results of the direct and soil sampling were used to supplement the species lists and better characterize the local fauna.

The actual species diversity and the proportion between the numbers of registered species are different for each sampling site. On one hand they are determined by the potential species capacity of the different habitats, the feeding and living conditions they offer, and on the other they reflect the species' specific bio- 
Table 1. List of millipedes collected in Shumen and Shumen Plateau by pitfall traps, direct and soil sampling with their absolute numbers.

Таблица 1. Видовой состав и количество многоножек класса Diplopoda, установленных в городе Шумен и Шуменском плато с использованием наземных ловушек, а также методом ручного сбора и проб почвы.

\begin{tabular}{|c|c|c|c|c|c|c|}
\hline \multirow[t]{2}{*}{ No. } & \multirow[t]{2}{*}{ Species } & \multirow{2}{*}{$\begin{array}{l}\text { Species } \\
\text { code }\end{array}$} & \multicolumn{4}{|c|}{ Total number of the catches } \\
\hline & & & $\begin{array}{l}\text { Pitfall } \\
\text { traps }\end{array}$ & $\begin{array}{c}\text { Hand } \\
\text { collecting }\end{array}$ & $\begin{array}{c}\text { Soil samples } \\
\text { and Tüllgren } \\
\text { extraction }\end{array}$ & Total \\
\hline & DIPLOPODA & & & & & \\
\hline & Order Glomerida & & & & & \\
\hline & Family Glomeridae & & & & & \\
\hline \multirow[t]{2}{*}{1.} & Glomeris hexasticha Brandt, 1833 & Ghex & 57 & 4 & 1 & 62 \\
\hline & FamilyDoderiidae & & & & & \\
\hline \multirow[t]{3}{*}{2.} & Trachyspheara costata (Waga, 1857) & Tkot & $\mathbf{0}$ & 30 & $\mathbf{0}$ & 30 \\
\hline & Order Polydesmida & & & & & \\
\hline & Family Polydesmidae & & & & & \\
\hline 3. & Polydesmus complanatus (Linnaeus, 1761) & Pcom & 95 & 38 & $\mathbf{0}$ & 133 \\
\hline 4. & Polydesmus denticulatus C.L. Koch, 1847 & Pden & 108 & 33 & 10 & 151 \\
\hline 5. & Polydesmus renschi Schubart, 1934 & Pren & 7 & $\mathbf{0}$ & $\mathbf{0}$ & 7 \\
\hline \multirow[t]{2}{*}{6.} & Polydesmus mediterraneus Daday, 1899 & Pmed & 10 & $\mathbf{0}$ & $\mathbf{0}$ & 10 \\
\hline & Family Paradoxosomatidae & & & & & \\
\hline \multirow[t]{3}{*}{7.} & Strongylosoma stigmatosum (Eichwald, 1830) & Ssti & 7 & $\mathbf{0}$ & $\mathbf{0}$ & 7 \\
\hline & Order Chordeumatida & & & & & \\
\hline & Family Anthroleucosomatidae & & & & & \\
\hline \multirow[t]{2}{*}{8.} & Anamastigona bilselii (Verhoeff, 1940) & Abil & 46 & 31 & 5 & 82 \\
\hline & Family Craspedosomatidae & & & & & \\
\hline \multirow[t]{3}{*}{9.} & Craspedosoma transsylvanicum Verhoeff, 1897 & Ctrans & 5 & 3 & $\mathbf{0}$ & 8 \\
\hline & Order Julida & & & & & \\
\hline & Family Blaniulidae & & & & & \\
\hline \multirow[t]{2}{*}{10.} & Nopoiulus kochii (Gervais, 1847) & Nkoch & 31 & 5 & 68 & 104 \\
\hline & Family Julidae & & & & & \\
\hline 11. & Leptoiulus trilineatus(C.L. Koch, 1847) & Ltri & 1474 & 495 & 86 & 2055 \\
\hline 12. & Typhloiulus kotelensis Jawlowski, 1938 & Tkot & $\mathbf{0}$ & $\mathbf{0}$ & 3 & 3 \\
\hline 13. & Cylindroiulus boleti (C.L. Koch, 1847) & Cbol & 302 & 158 & 145 & 605 \\
\hline 14. & Megaphyllum bosniense (Verhoeff, 1897) & Mbos & 437 & 74 & 41 & 552 \\
\hline 15. & Megaphyllum lictor (Attems, 1904) & Mlic & 5 & 5 & $\mathbf{0}$ & 10 \\
\hline 16. & Megaphyllum transsylvanicum (Verhoeff, 1897) & Mtrans & 618 & 93 & 35 & 746 \\
\hline 17. & Megaphyllum unilineatum (C.L. Koch, 1838) & Muni & 93 & 18 & $\mathbf{0}$ & 111 \\
\hline 18. & Pachyiulus hungaricus (Karsch, 1881) & Phun & 34 & 114 & 22 & 170 \\
\hline 19. & Pachyiulus varius (Fabricius, 1781) & Pvar & 7 & 68 & $\mathbf{0}$ & 75 \\
\hline \multirow[t]{2}{*}{20.} & Apfelbeckiella trnowensis trnowensis(Verhoeff, 1928) & Atrn & 106 & 45 & 5 & 156 \\
\hline & Total number of catches: & & 3442 & 1214 & 421 & 5077 \\
\hline
\end{tabular}

logical capabilities for adaptation and reproduction [Trojan, 1994]. Depending on the amount of collected individuals of particular species and their distribution in the studied habitats, myriapods can be classified into three groups (Tables 1 and 2; Tables 3A and 3B).

The first group includes species that are found in small number (up to 10 individuals) for the two-year study period. To this group belong: Polydesmus renschi, P. mediterraneus, Strongylosoma stigmatosum, Craspedosoma transsylvanicum, Megaphyllum lictor (Table 1) and Pachyiulus varius, Scutigera coleoptrata, Lithobius erythrocephalus, L. aff. melanops, L. parietum, L. schuleri, $L$. crassipes, $L$. beroni, $L$. aff. micropodus, Harpolithobius sp.n. 1, Harpolithobius sp.n. 2, Scolopendra cingulata, Cryptops parisi, Cryptops trisulcatus (2 individuals), Shendyla carniolensis and
Henia illyrica (Table 2). These species are likely to be of very high specialization and having specific requirements to their habitat. Therefore coming across them at the sampling sites is more likely a coincidence rather than a pattern. They are of limited distribution in the research areas and have been so far registered in a very few habitats (Tables 3A and 3B).

The second group includes species that are found in all or nearly all explored habitats in relatively high numbers. These are, among millipedes: Leptoiulus trilineatus, Megaphyllum bosniense, M. transsylvanicum, Cylindroiulus boleti, Polydesmus complanatus, $P$. denticulatus, as well as the centipedes Lithobius forficatus, L. muticus, L. nigripalpis, Cryptops anomalans and Clinopodes flavidus. It is noteworthy that among Diplopoda only species of Julida inhabit the open mead- 
Table 2. List of centipedes collected in Shumen and Shumen Plateau by pitfall traps, direct sampling and soil samples with their absolute numbers.

Таблица 2. Видовой состав и количество многоножек класса Chilopoda, установленных в городе Шумен и Шуменском плато с использованием наземных ловушек, а также методом ручного сбора и проб почвы.

\begin{tabular}{|c|c|c|c|c|c|c|}
\hline \multirow[t]{2}{*}{ No. } & \multirow[t]{2}{*}{ Species } & \multirow{2}{*}{$\begin{array}{l}\text { Species } \\
\text { code }\end{array}$} & \multicolumn{4}{|c|}{ Total number of catches } \\
\hline & & & $\begin{array}{c}\text { Pitfall } \\
\text { traps }\end{array}$ & $\begin{array}{c}\text { Hand } \\
\text { collecting }\end{array}$ & $\begin{array}{c}\text { Soil samples } \\
\text { and Tüllgren } \\
\text { extraction }\end{array}$ & Total \\
\hline & CHILOPODA & & & & & \\
\hline & Order Scutigeromorpha & & & & & \\
\hline & Family Scutigeridae & & & & & \\
\hline \multirow[t]{3}{*}{1.} & Scutigera coleoptrata (Linnaeus, 1758) & Scol & 5 & 3 & $\mathbf{0}$ & 8 \\
\hline & Order Lithobiomorpha & & & & & \\
\hline & Family Lithobiidae & & & & & \\
\hline 2. & Eupolybothrus (M.) transsylvanicus (Latzel, 1882) & Etrans & 32 & 8 & $\mathbf{0}$ & 40 \\
\hline 3. & Lithobius (L.) erythrocephalus C.L. Koch, 1847 & Lery & 1 & $\mathbf{0}$ & $\mathbf{0}$ & 1 \\
\hline 4. & Lithobius (L.) forficatus (Linnaeus, 1758) & Lfor & 86 & 150 & 3 & 239 \\
\hline 5. & Lithobius (L.) lucifugus L. Koch, 1862 & Lluc & 41 & 15 & 15 & 71 \\
\hline 6. & Lithobius (L.) mutabilis L. Koch, 1862 & Lmuta & $\mathbf{5 0}$ & 17 & $\mathbf{0}$ & 67 \\
\hline 7. & Lithobius (L.) muticus C.L. Koch, 1847 & Lmuti & 81 & 22 & 59 & 162 \\
\hline 8. & Lithobius (L.) nigripalpis L. Koch, 1867 & Lnig & 708 & 282 & 35 & 1025 \\
\hline 9. & Lithobius aff. melanops Newport, 1845 & Lafmel & 3 & 2 & $\mathbf{0}$ & 5 \\
\hline 10. & Lithobius (L.) aff. oglednicus Ribarov, 1987 & Lafogl & 12 & 6 & 1 & 19 \\
\hline 11. & Lithobius (L.) parietum Verhoeff, 1899 & Lpar & 1 & $\mathbf{0}$ & $\mathbf{0}$ & 1 \\
\hline 12. & Lithobius (L.) schuleri Verhoeff, 1925 & Lsch & 3 & 1 & $\mathbf{0}$ & 4 \\
\hline 13. & Lithobius (M.) crassipes L. Koch, 1862 & Lcras & 4 & 22 & 26 & 52 \\
\hline 14. & Lithobius (S.) beroni Negrea, 1965 & Lber & 5 & 39 & 20 & 64 \\
\hline 15. & Lithobius (S.) aff.micropodus (Matic, 1980) & Lafmic & 2 & 1 & $\mathbf{0}$ & 3 \\
\hline 16. & Lithobius (S.) microps Meinert, 1868 & Lmic & $\mathbf{0}$ & 4 & 83 & 87 \\
\hline 17. & Harpolithobius sp.n. 1 (radui group) & Hafrad & 4 & 10 & 1 & 15 \\
\hline \multirow[t]{3}{*}{18.} & Harpolithobius sp.n. 2 & Hn.sp. & 2 & $\mathbf{0}$ & $\mathbf{0}$ & 2 \\
\hline & Order Scolopendromorpha & & & & & \\
\hline & Family Scolopendridae & & & & & \\
\hline \multirow[t]{2}{*}{19.} & Scolopendra cingulata Latreille, 1829 & Scin & 3 & 2 & $\mathbf{0}$ & 5 \\
\hline & Family Cryptopidae & & & & & \\
\hline 20. & Cryptops anomalans Newport, 1844 & Cano & 113 & 38 & 48 & 199 \\
\hline 21. & Cryptops parisi Brölemann, 1920 & Cpar & 3 & 23 & 26 & 52 \\
\hline \multirow[t]{3}{*}{22.} & Cryptops trisulcatus Brölemann, 1902 & Ctri & 2 & $\mathbf{0}$ & $\mathbf{0}$ & 2 \\
\hline & Order Geophilomorpha & & & & & \\
\hline & Family Schendylidae & & & & & \\
\hline 23. & Shendyla carniolensis Verhoeff, 1902 & Scar & 5 & 1 & 6 & 12 \\
\hline 24. & Shendyla aff. delicatula Kaczmarek, 1969 & Safdel & $\mathbf{0}$ & $\mathbf{0}$ & 1 & 1 \\
\hline 25. & Shendyla aff. tyrolensis (Meinert, 1870) & Saftyr & $\mathbf{0}$ & $\mathbf{0}$ & 5 & 5 \\
\hline \multirow[t]{2}{*}{26.} & Shendyla aff. walachica Verhoeff, 1900 & Safwal & $\mathbf{0}$ & $\mathbf{0}$ & 3 & 3 \\
\hline & Family Geophilidae & & & & & \\
\hline 27. & Geophilus flavus (De Geer, 1778) & Gfla & $\mathbf{0}$ & $\mathbf{0}$ & 13 & 13 \\
\hline 28. & Clinopodes flavidus C.L. Koch, 1847 & Cfla & 34 & 125 & 254 & 413 \\
\hline \multirow[t]{2}{*}{29} & Stenotaenia linearis (C.L. Koch, 1835) & Slin & 12 & 3 & 52 & 64 \\
\hline & Family Dignathodontidae & & & & & \\
\hline \multirow[t]{2}{*}{30.} & Henia illyrica (Meinert, 1870) & Hill & 3 & 19 & 51 & 73 \\
\hline & Family Linotaeniidae & & & & & \\
\hline 31. & Strigamia crassipes (C.L. Koch, 1835) & Scras & 12 & 17 & 13 & 42 \\
\hline 32. & Strigamia engadina (Verhoeff, 1935) & Seng & $\mathbf{0}$ & 1 & $\mathbf{0}$ & 1 \\
\hline \multirow[t]{2}{*}{33.} & Strigamia transsilvanica (Verhoeff, 1928) & Strans & $\mathbf{0}$ & $\mathbf{0}$ & 3 & 3 \\
\hline & Total number of catches: & & 1227 & 811 & 718 & 2756 \\
\hline
\end{tabular}

ow (RV) characterized by lawn leaf litter with extremely adverse conditions during the hot and dry summer months. These are mostly polytopic species that are able to live in more xeric conditions.
The third group is represented by species that inhabit limited number of habitats and are of medium number. These are: Glomeris hexasticha, Anamastigona bilselii, Nopoiulus kochii, Megaphillum unilinea- 


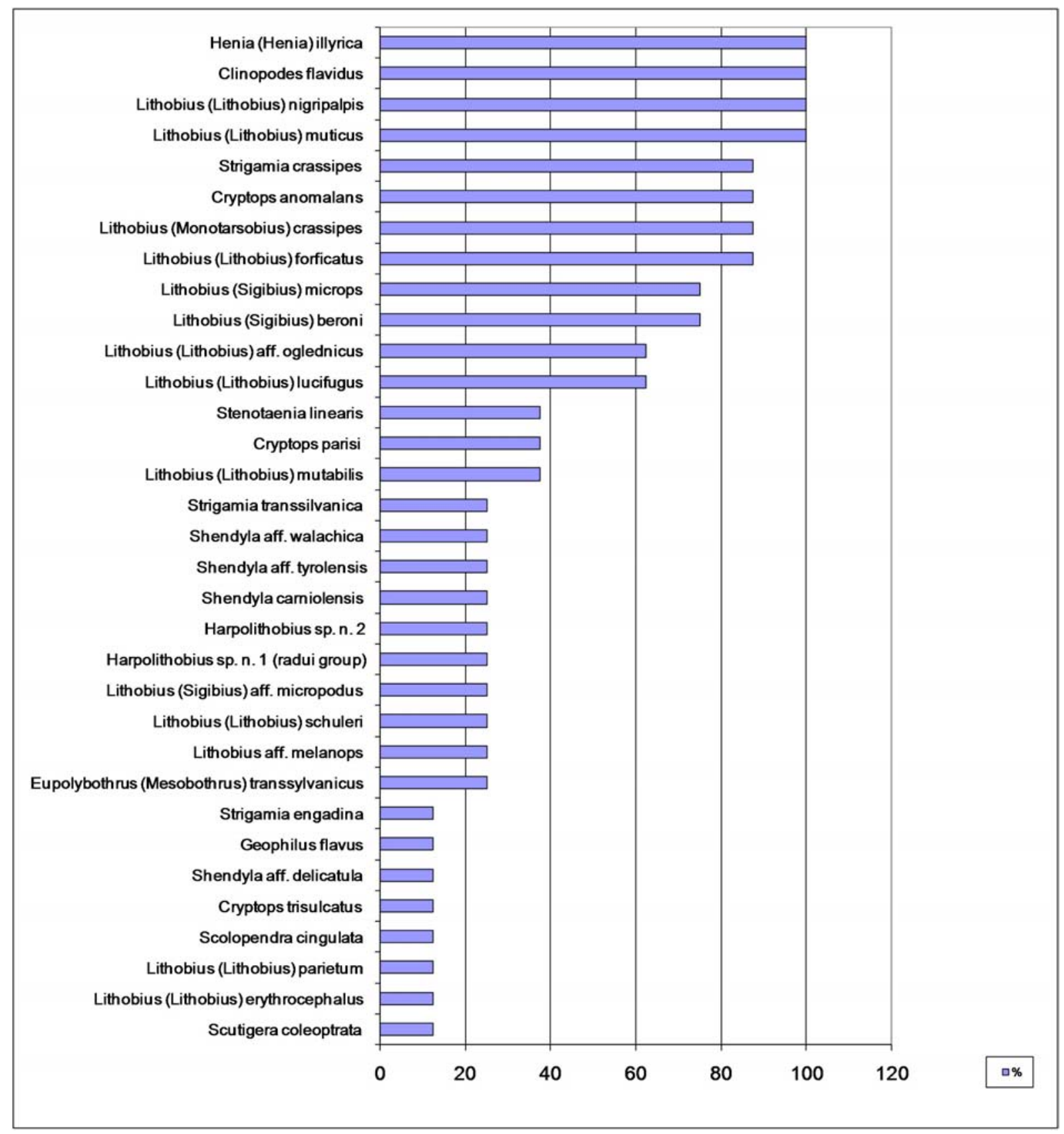

Fig. 2. Perseverance (invariability) in the presence of centipede species, found in Shumen and the Shumen Plateau in urban, suburban and natural habitats.

Рис. 2. Неизменяемость (устойчивость) в присутствии видов класса Chilopoda, установленных в городе Шумен и Шуменском плато в городских, пригородных и природных местообитаниях.

tum, Pachyiulus hungaricus, Apfelbeckiella trnowensis trnowensis, Eupolybothrus transsylvanicus, Lithobius lucifugus, L. mutabilis, L. aff. oglednicus, Stenotaenia linearis and Strigamia crassipes. Unlike the first and the second group, these species could become dominant in the area if successfully adapt by shifting and narrowing the ecological niches of the euraceous species.

According to Tishler's scale (Fig. 2) only 4 centipede species are common in the explored habitats and are present in all sampling sites, and hence could be considered eurytopic: Lithobius nigripalpis, L. muticus, Clinopodes flavidus and Henia illyrica. They, along with Lithobius forficatus, L. crassipes, Cryptops anomalans and Strigamia crassipes, which were found in 7 of the explored habitats, compose to a large extend the specific character of the centipede fauna in the area.

Centipedes exhibit more pronounced preference for certain habitats. Ten of the registered species $(30 \%)$ occur in two of the sites and 8 species $(24 \%)$ live in 


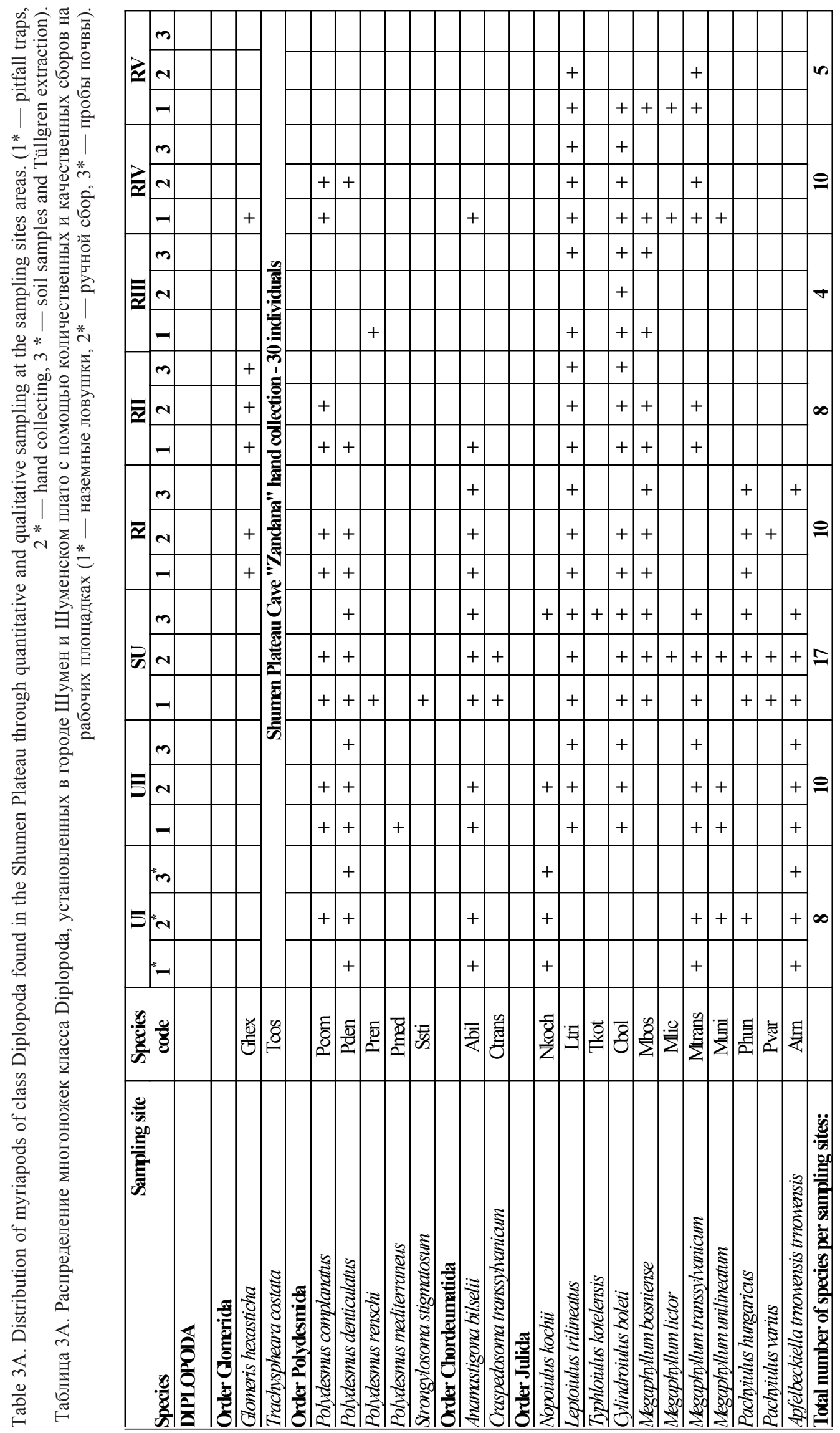




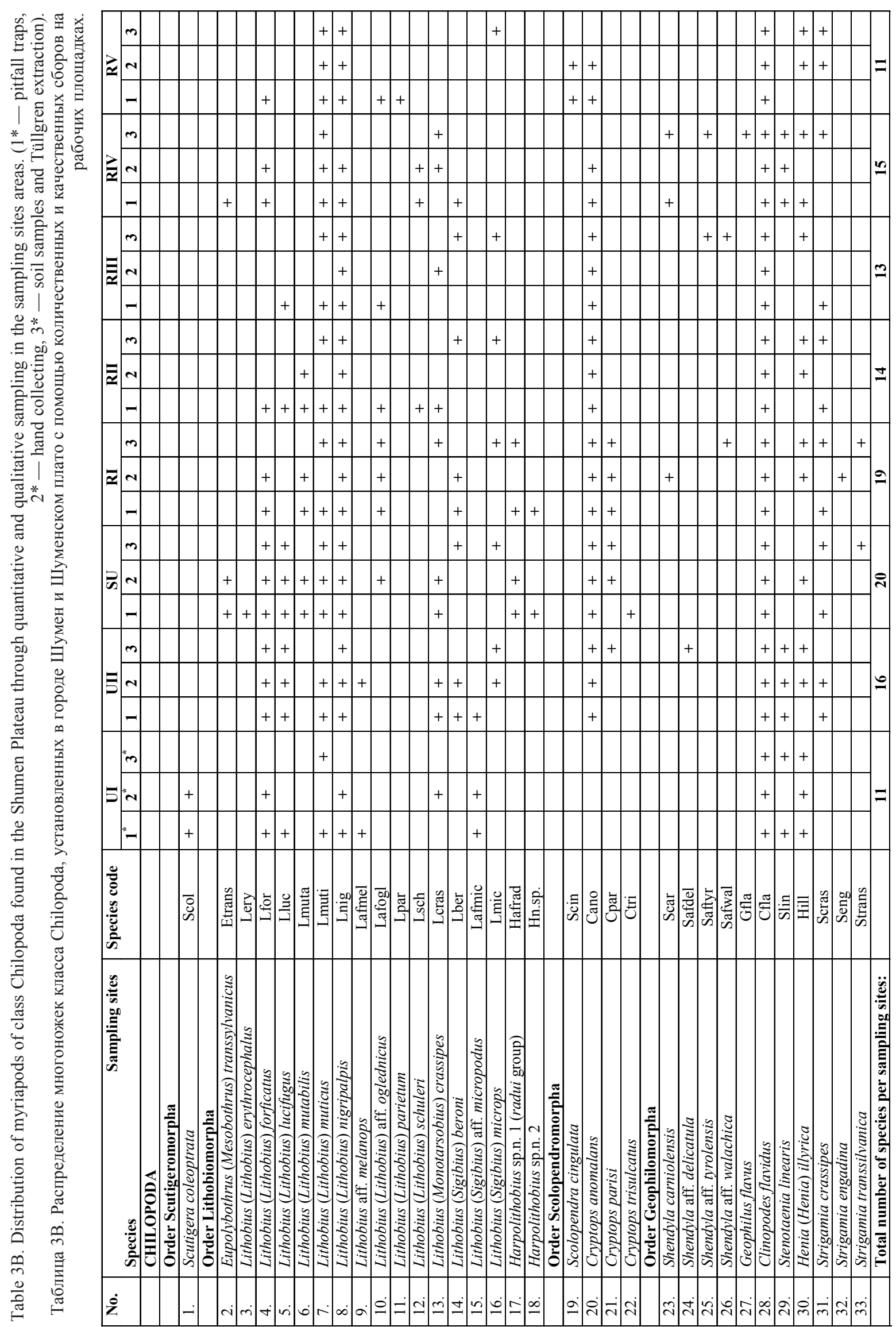




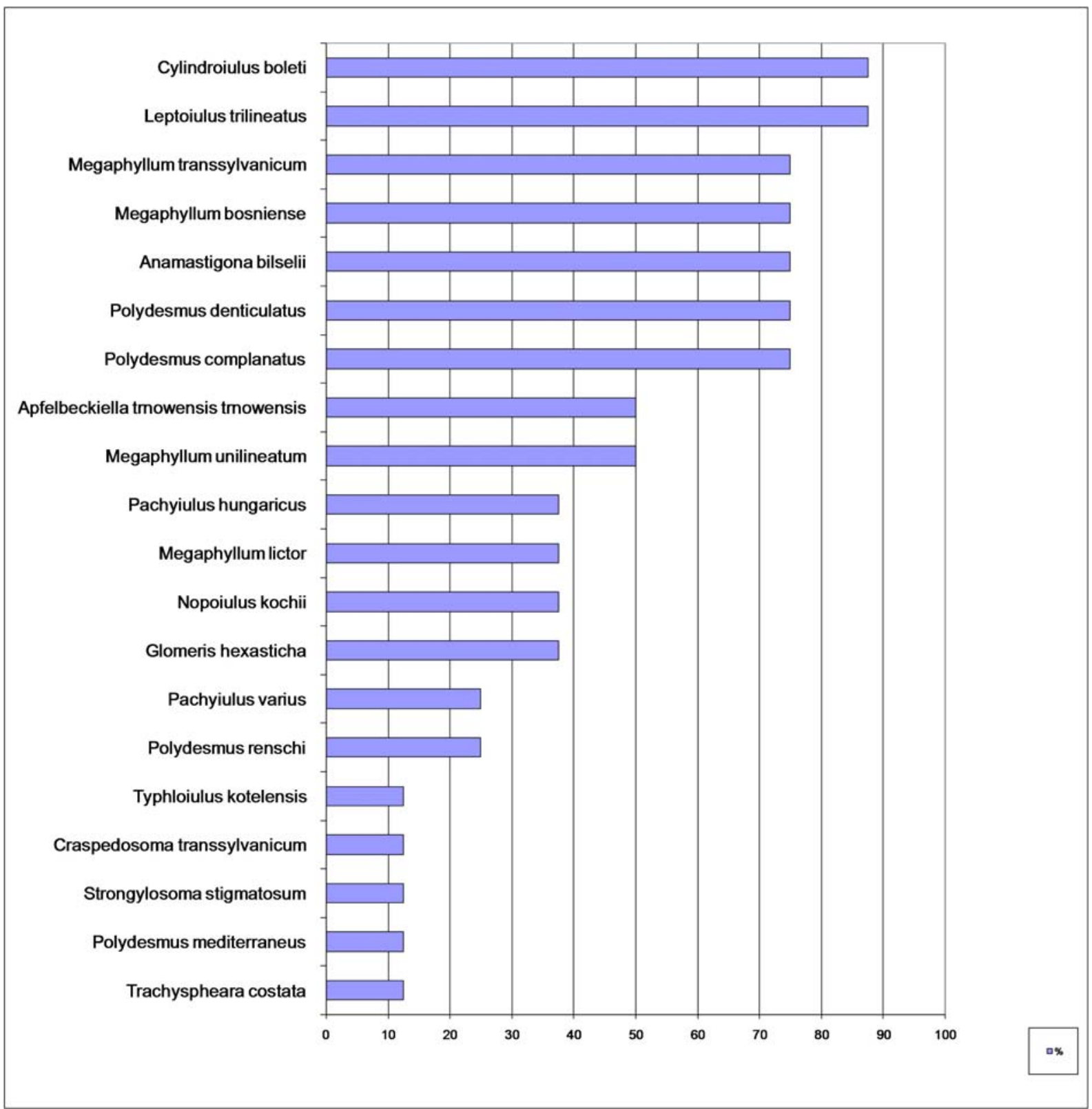

Fig. 3. Perseverance (invariability) in the presence of millipede species found in Shumen and the Shumen Plateau in urban, suburban and natural habitats.

Рис. 3. Неизменяемость (устойчивость) в присутствии видов класса Diplopoda, установленных в городе Шумен и Шуменском плато в городских, пригородных и природных местообитаниях.

only one habitat. These are mostly species that belong to the first group and are very specialized and form the specific outlook of the centipede community in the corresponding habitat.

There are no millipedes present in all of the explored habitats, which indicates they are highly specialized and oriented to certain types of plant formation (Fig. 3). This is largely due to their trophic dependence [Dunger, 1958; Striganova, 1969, 1974]. The polytrophic Leptoiulus trilineatus and Cylindroiulus boleti, found in 7 sites have high tolerance to anthropogenic pressure and have been registered only in the most urbanized parts of the city. They, along with Megaphyllum transsylvanicum, M. bosniense, Anamastigona bilselii, Polydesmus denticulatus and P. complanatus, established in 6 habitats dominate in the millipede communities in the region of Shumen and the Shumen Plateau.

Being registered in only in one habitat, five millipede species exhibit very high specialization and can be categorized as oligotopic. These are S. stigmatosum, C. transsylvanicum and T. kotelensis, hitherto found only in the suburban site; $P$. mediterraneus registered only in the park of the Shumen University, and $T$. costata - found in Zandana cave. 


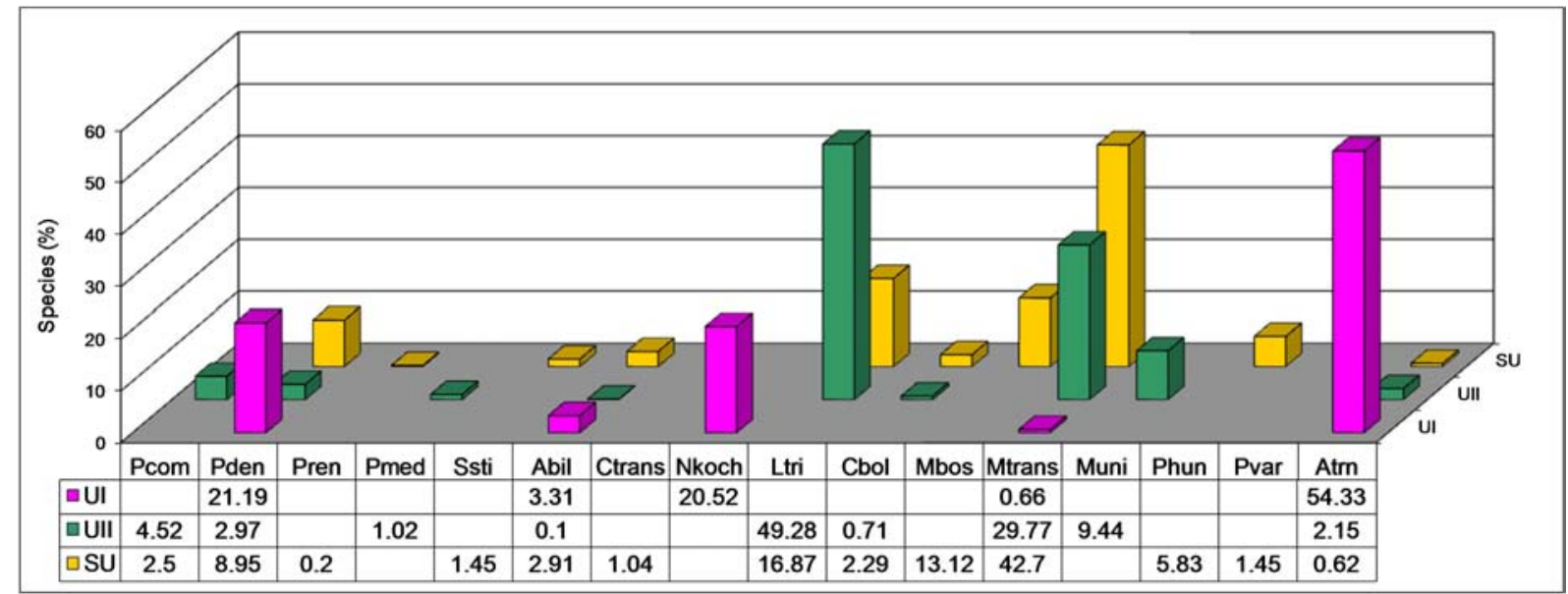

Fig. 4. Proportion of millipede species in urban and suburban green areas of Shumen (based on data from pitfall traps only).

Рис. 4. Соотношение видов из класса Diplopoda в районах городских и пригородных зеленых насаждений Шумена (только наземные ловушки).

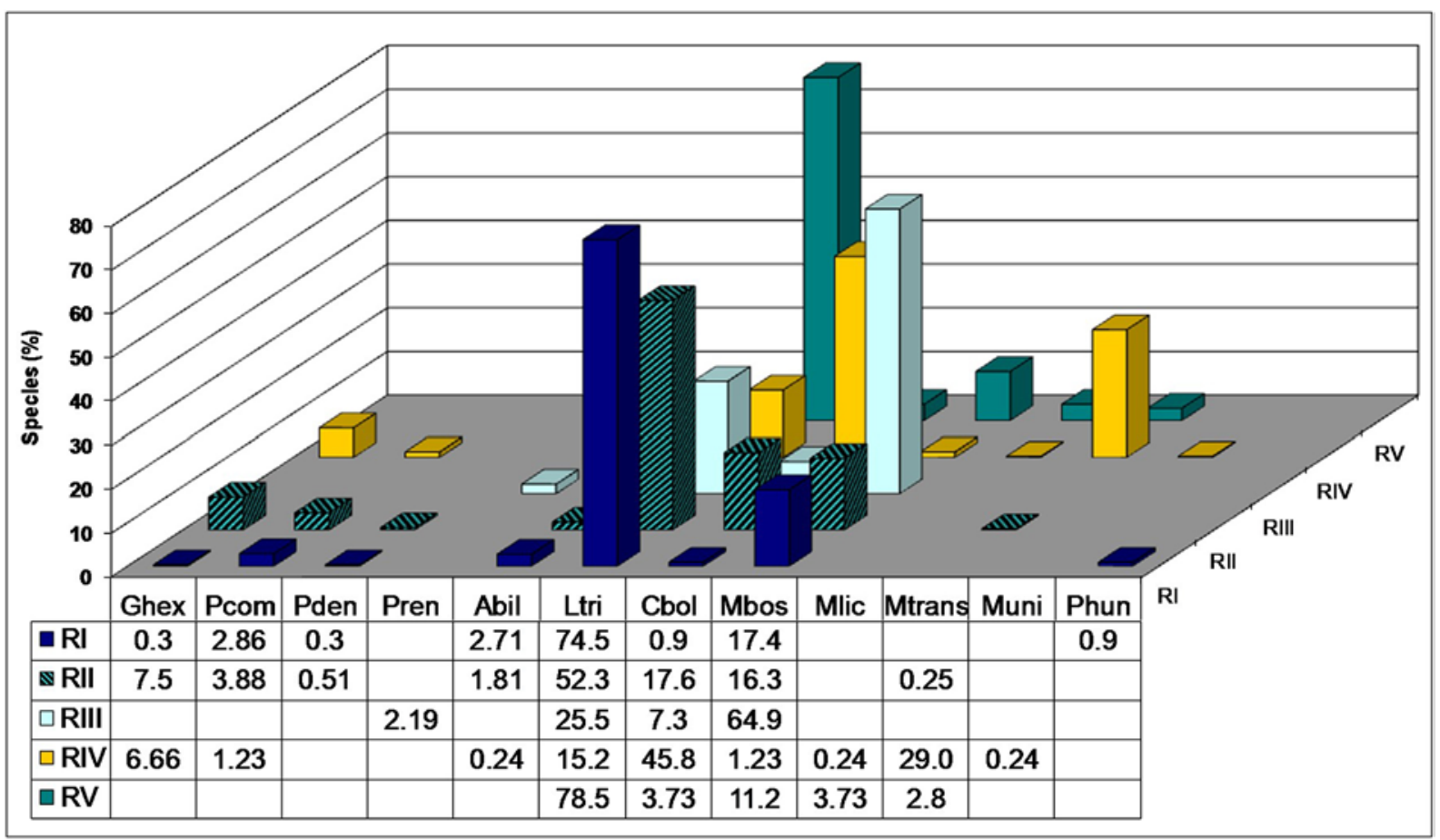

Fig. 5. Proportion of millipede species in the natural habitats of Shumen Plateau (based on data from pitfall traps only).

Рис. 5. Соотношение видов из класса Diplopoda в природных местообитаниях Шуменского плато (только наземные ловушки).

The cluster analysis of the quality composition has determined a degree of similarity of the examined communities in urban, suburban and rural habitats. The results show that no sampling sites are completely identical in their species composition. The degree of similarity of the millipede fauna in urban and suburban green areas is relatively high. Of the 22 species registered at the Shumen University park and at Kioshkovete park, about one third ( 7 species) are found in both sites. The degree of similarity between the most highly urbanized city garden (UI), and the suburban area (SU) is lower. Of all 18 species found there only 4 were typical for both locations (Fig. 4).

The most urbanized parts of the city (UI and UII) are characterized by relatively poor species composition. However, they exhibit a high degree of similarity four of the five millipedes registered in the city park are also found in the Shumen University park. The 
Table 4. Czekanowski-Dice-Sörensen's index values (Qs) for the millipede communities in urban and natural habi-

tats

Таблица 4. Значения индекса Czekanowski-Dice-Sцrensen $(\mathrm{Qs})$ для диплоподных сообщест в урбанизированных и природных местообитаниях.

\begin{tabular}{|c|c|c|c|c|c|c|c|c|}
\hline Sampling sites & UI & UII & SU & RI & RII & RIII & RIV & RV \\
\hline UI & 1 & & & & & & & \\
\hline UII & 0.57 & 1 & & & & & & \\
\hline SU & 0.44 & 0.63 & 1 & & & & & \\
\hline RI & 0.30 & 0.58 & 0.66 & 1 & & & & \\
\hline RII & 0.46 & 0.70 & 0.66 & $\mathbf{0 . 8 7}$ & 1 & & & \\
\hline RIII & $\mathbf{0 . 0 0}$ & 0.30 & 0.47 & 0.50 & 0.50 & 1 & & \\
\hline RIV & 0.28 & 0.66 & 0.54 & 0.70 & 0.82 & 0.46 & 1 & \\
\hline RV & 0.2 & 0.42 & 0.44 & 0.46 & 0.61 & 0.66 & 0.71 & 1 \\
\hline
\end{tabular}

millipede fauna of park Kyoshkovete is more alike the Bukaka reserve - out of the 21 registered species, 7 were found in both works sites.

The natural habitat of the Shumen Plateau exhibits a much higher degree of similarity in terms of millipede communities, probably conditioned by the similarity in species composition of their plant formations. The deciduous-coniferous forest shows great resemblance to the Bukaka reserve ( 7 out of 16 species were found in both sites) as the two sampling sites have the same edificators.

The most impoverished and peculiar millipede fauna was found in the open meadow (RV) and the hornbeam forests (RIII). This is mainly due to the fact they both offer xeric conditions and limited food supplies (Fig. 5).

The level of similarity in the millipede species composition in the communities of the examined area varies widely - Sorensen's index was only 0.2 in the city park and in the open ridge meadow and it reaches 0.87 at the Bukaka reserve and at the deciduous-coniferous forest. Two of the worksites (UI and RIII) have no common species and the Qs there equal 0.00 (Table 4). Very low index values were detected between the most urbanized part of the city (UI) and the natural habitats of the Shumen Plateau - 0.2 (with RV), 0.28 (with RIV) and 0.3 (with RI).

The millipede fauna in the examined region is very similar in the different sampling sites. It is divided into two main groups with a relatively high degree of similarity (0.46) (Fig. 6). The first group is formed by the urban and suburban green areas and part of the natural habitats of the Shumen Plateau.

Although the species composition of the millipede component in the 5 sites shows a high degree of similarity (0.66) the millipede communities of both urban sites - UI and UII are placed in a separate group with the highest degree of similarity - 0.84 . The species composition of the park Kyoshkovete (SU) shows a great similarity to that of the Bukaka reserve (RI) 0.81 . Along with the deciduous-coniferous forest the three sites form a single group. This is likely due to the similar nutritional conditions in these habitats. The main edificator in Bukaka and in the mixed forest is
Table 5. Czekanowski-Dice-Sörensen's index values (Qs) for the centipede communities in urban and natural habi-

tats.

Таблица 5. Значения индекса Czekanowski-Dice-Sцrensen (Qs) для хилоподных сообществ в урбанизированных и природных местообитаниях.

\begin{tabular}{|c|l|l|l|l|l|l|l|l|}
\hline Sampling sites & UI & UII & SU & RI & RII & RIII & RIV & RV \\
\hline UI & 1 & & & & & & & \\
\hline UII & 0.66 & 1 & & & & & & \\
\hline SU & 0.41 & 0.64 & 1 & & & & & \\
\hline RI & 0.36 & 0.60 & 0.69 & 1 & & & & \\
\hline RII & 0.47 & 0.72 & 0.40 & 0.69 & 1 & & & \\
\hline RIII & 0.47 & 0.66 & 0.57 & 0.63 & $\mathbf{0 . 7 7}$ & 1 & & \\
\hline RIV & 0.57 & 0.54 & 0.48 & 0.52 & 0.54 & 0.44 & 1 & \\
\hline RV & $\mathbf{0 . 3 3}$ & 0.52 & 0.45 & 0.60 & 0.63 & 0.66 & 0.52 & 1 \\
\hline
\end{tabular}

Fagus moesiaca, which is why the millipede communities are very similar in composition. Kyoshkovete park borders with an array of beech forest, which is probably the main source of immigrants in this area, and therefore the species composition of the millipede community resembles that of the natural habitats.

The remaining three sampling sites in the park (RIII, RIV, and RV) form the second group in which the greatest degree of similarity -0.65 was observed between the hornbeam and pine forest and the open meadow crest (0.63). The three habitats form a homogenous group. They are characterized by the most poor species composition, probably due to the specificity of their food resources and more xeric conditions they offer.

As a whole, the centipede fauna in the examined area shows a much higher degree of similarity than that of the millipede fauna. This applies to both urban and suburban green spaces and the natural habitats of the Shumen Plateau. Sorensen's index (Table 5) varies in much narrower margins in comparison to the millipede fauna - from 0.33 in the city park and the open ridge to 0.77 in the meadow between the hornbeam and the mixed forests.

Again, as with millipedes there is a great similarity in the species composition of the urban sites - UI and UII, which have 7 species in common (Fig. 7).

The similarity between the centipede fauna of the urban green areas and the suburban area varies widely - from relatively low degree between the city park and park Kyoshkovete (total of 5 species out of the 24 registered ones; Qs $=0.41$ ) to a significantly higher degree between park Kyoshkovete and the Shumen University park (out of 25 species, only 8 are found in both sites; Qs = 0.64).

In the natural habitat of the plateau for the Chilopoda the greatest degree of similarity exhibit the communities in the mixed deciduous-coniferous forest (RII) and the hornbeam forests (RIII) -0.77 , with a total of 7 common for both sites species out of the 18 registered ones (Fig. 8). There is a relatively equal degree of similarity between the reserve Bukaka and the mixed deciduous-coniferous forest (0.69) and the hornbeam forest and the open meadow crest (0.66) (Table 5). The 


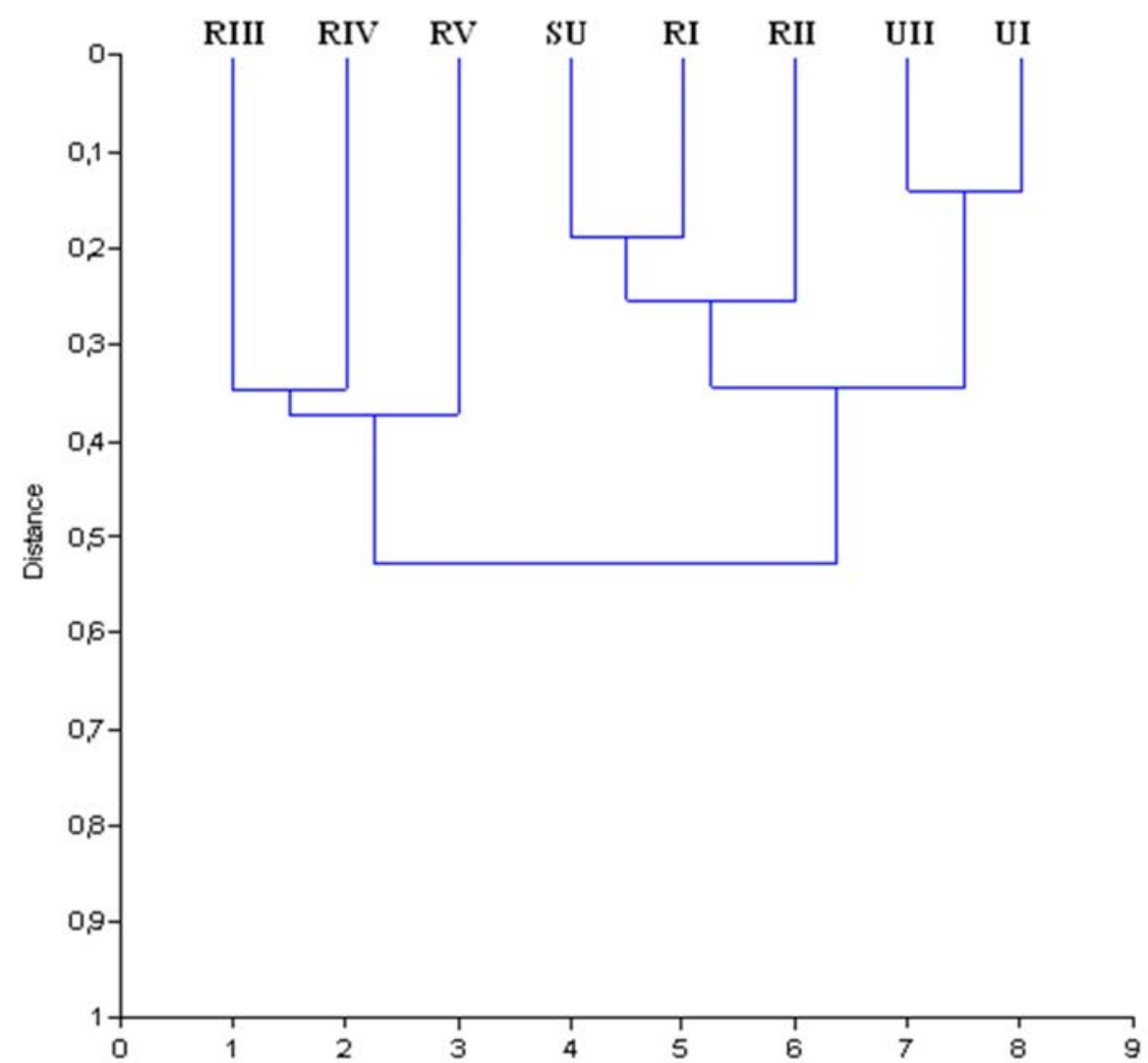

Fig. 6. Dendrogram of similarity in species composition of the millipede communities in urban and rural habitats.

Рис. 6. Дендрограмма сходства в видовом составе диплоподных сообществ в городских и пригородных местообитаниях.

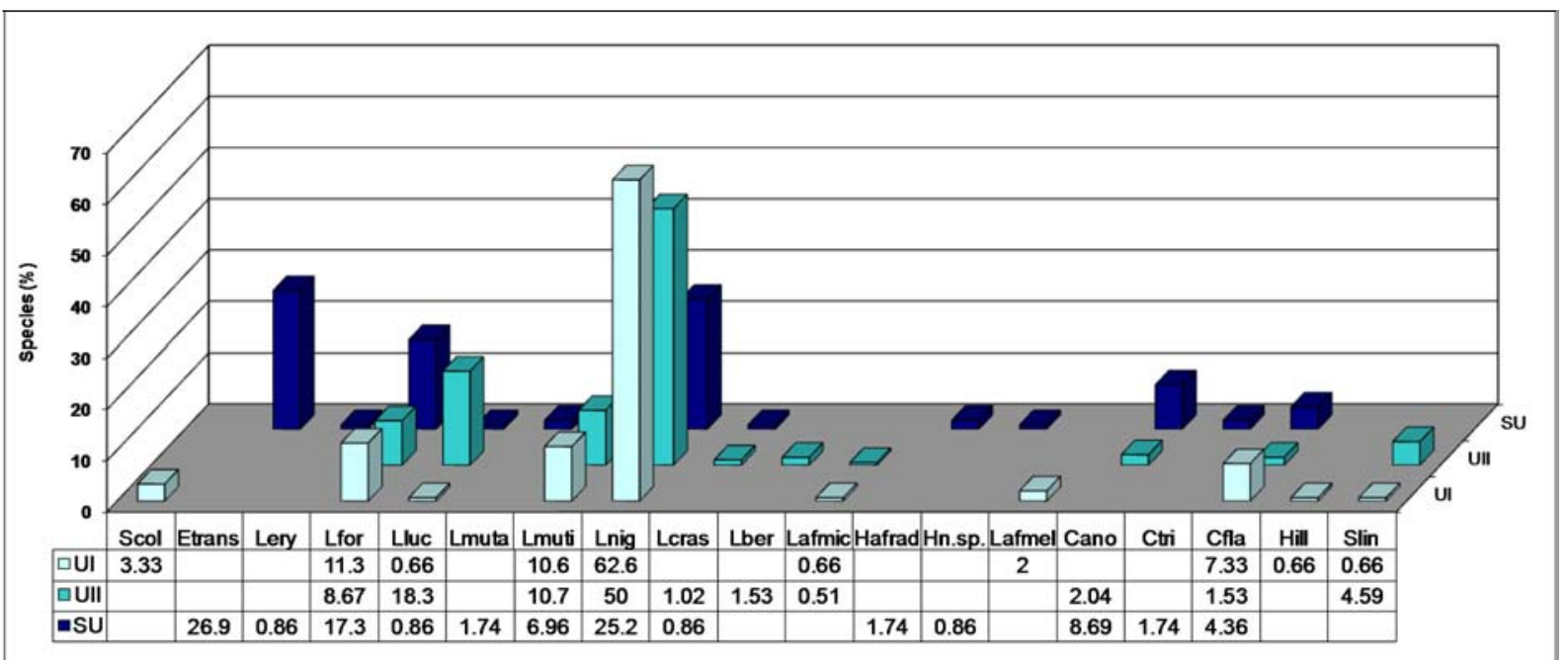

Fig. 7. Proportion of centipede species in urban and suburban green areas of Shumen (based on data from pitfall traps only).

Рис. 7. Соотношение видов из класса Chilopoda в районах городских и пригородных зеленых насаждений Шумена (только наземные ловушки).

lowest degree of similarity was found between the hornbeam and pine forest and between the pine forest and the open meadow. The most common species in all sampling sites at the Shumen Plateau is Lithobius nigripalpis, which exhibits significantly higher tolerance to drought than other species [Zapparoli, 1999]. It penetrates the deep layers of leaf litter with higher and relatively constant humidity, where adults and fast moving individuals are able to compensate more easily for the water loss. Moreover the conditions appear optimal for earlier stages of the species development [Frund, 1987]. This is probably the reason why it is the dominant species in all examined natural habitats in the region - its share in the total catch was comparatively 


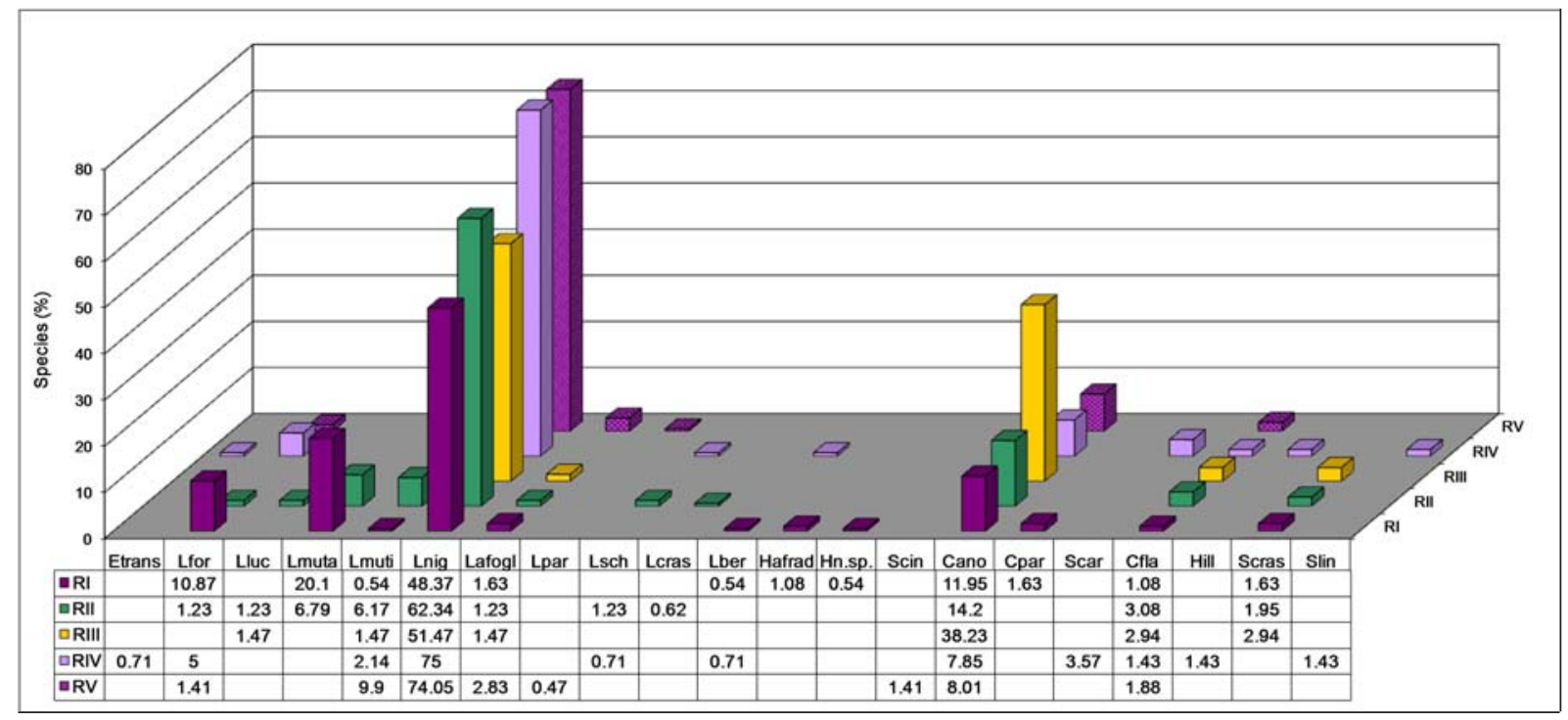

Fig. 8. Proportion of centipede species in the natural habitats of Shumen Plateau (based on data from pitfall traps only).

Рис. 8. Соотношение видов из класса Chilopoda в природных местообитаниях Шуменского плато (только наземные ловушки).

high and ranges from $48.37 \%$ in Bukaka reserve (RI) to $75 \%$ in the mixed deciduous-coniferous forest (RIV) (Fig. 8).

Centipede communities in the examined area are also divided into two main groups at a degree of similarity of 0.48 (Fig. 9). The first group includes the urban and suburban green as well as reserve Bukaka. In this group there are the two separate urban sites (UI and UII) with a degree of similarity 0.85 . Great similarity occurs between the communities in the suburban area and the reserve (0.83). The second group unites the remaining forest habitats of the plateau ridge and the open meadow. The highest degree of similarity was observed between the centipede fauna of the mixed forest and the hornbeam forest -0.79 , while the open meadow crest is logically separate from the forest habitats with a similarity degree of 0.4 .

\section{Discussion}

The myriapod fauna of Shumen is constituted primarily of native species and such from its surroundings. There isn't a single alien (introduced from another country or continent) element in the fauna, which is unusual given the size of the city, its long history, established trade relations with other regions since antiquity and the active transport of products from around the world. For comparison, Stoev [2004] finds two non-native species in Sofia (Oxidus gracilis, Pleurolithobius patriarchalis). The widespread in Europe species Lamyctes emarginatus, which is believed to have originated in Australasia, was not found in the city, although it is not rare in the country [Stoev, 2002] and often occurs in urban areas, frequently in flower pots in residential buildings.
The distribution of myriapods in the studied area is primarily determined by the specifics of the soil and climatic conditions and the composition of the plant formations found there, as well as the available food resource. In accordance with the concept of border (ecotonic) effect [Odum, 1971], the highest species diversity is evident in the suburban area (park Kyoshkovete), with a total of 37 registered species (17 millipedes and 20 centipedes - Tables 3A, B). Despite its partial urbanization to a large extent the park has preserved the natural character of its habitats. It serves as a transitional zone between the highly urbanized areas of the city and the habitats remaining unaffected by the anthropogenic influence in the Shumen Plateau. The area is characterized by high humidity throughout the whole year and relatively moderate temperatures in all seasons - higher than the temperature measured in winter at the Shumen plateau and significantly lower than that in the city center during the summer months. The centipedes being predators are not trophycally bound to a certain flora and have a much wider distribution in the studied habitats of the Shumen Plateau than most millipedes. However, there is some regularity in their distribution across the sampling sites, which is probably related to the presence of various specific microhabitats in different habitats.

The city greens in the central areas of the town are relatively poor in species, but at the same time they exhibit a higher degree of similarity to other highly urbanized habitats, such as the Shumen University park. This is consistent with the results of the study of Zapparoli [2002], who found a large heterogeneity of the fauna and relatively poor species composition while studying the centipedes of Rome. The same author concludes that most influenced by the anthropogenic 


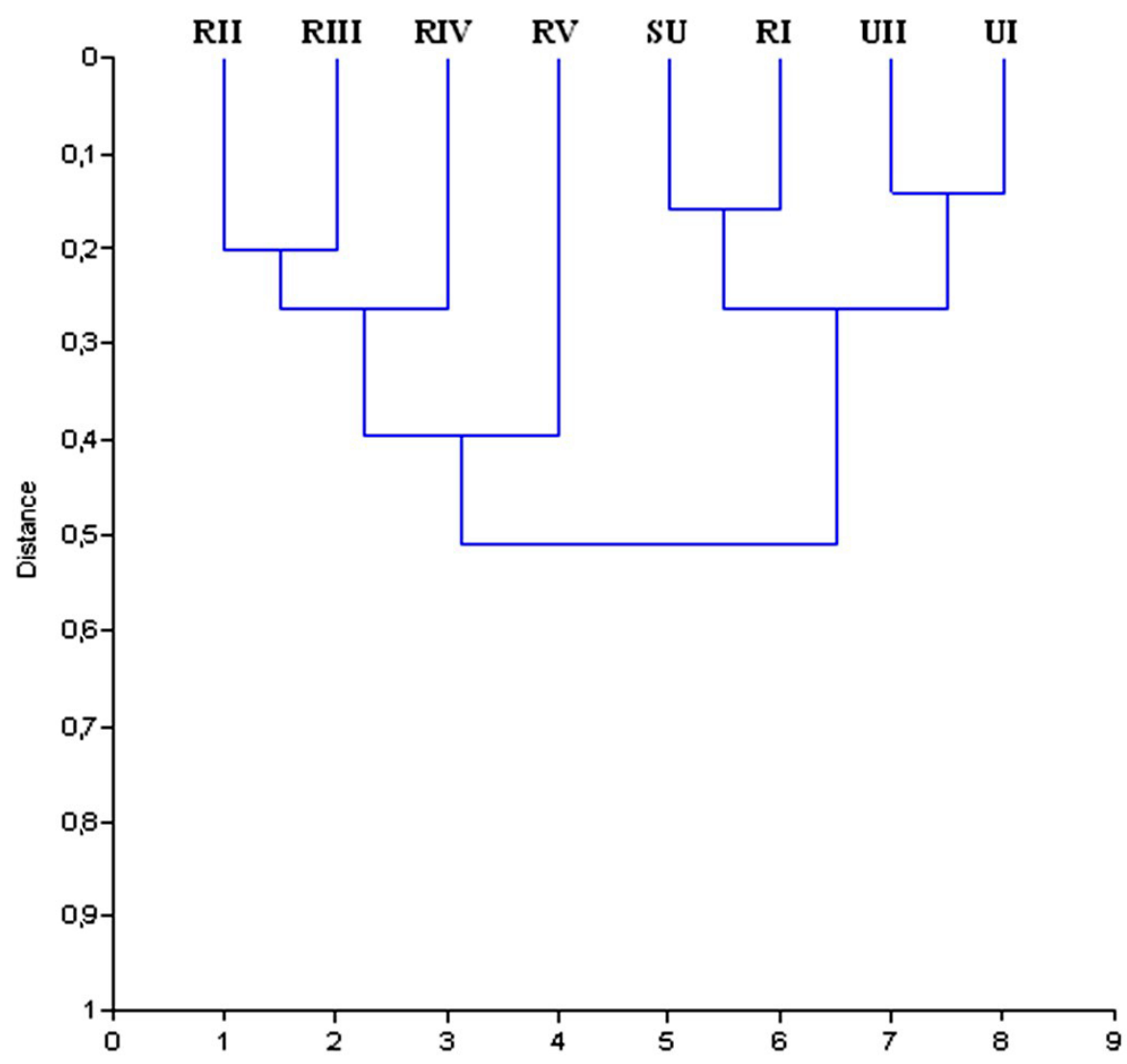

Fig. 9. Dendrogram of similarity in species composition of the centipede communities in urban and rural habitats.

Рис. 9. Дендрограмма сходства в видовом составе хилоподных сообществ в городских и пригородных местообитаниях.

pressures species are members of the orders Geophilomorpha and Scolopendromorpha, which is mostly due to their poor mobility and greater sensitivity to the environment. This was also confirmed by our study only 7 out of total of 15 species of these orders were established within the city borders. Seven out of the 8 Diplopoda species recorded in the city gardens, are common for the University park, while for Chilopoda all the 11 species were found in both habitats of the central urban zone. Several species were only registered in the less anthropogenically influenced surroundings of the city. Species showing restricted distribution and high specialization to particular environmental conditions, such as Strongylosoma stigmatosum, Craspedosoma transsylvanicum, Typhloiulus kotelensis, Lithobius erythrocephalus and Cryptops trisulcatus most likely cannot overcome the effects of the urban factors.

The highest species diversity, closer to that seen in natural habitats on the Shumen Plateau than in the central parts of the city, was recorded in park Kyoshkovete which has been subjected to relatively weak anthropogenic pressures. Of all the 37 myriapod species registered in the urban area, 18 centipede species and 13 millipede species (84\%) occur in the natural habitats of the plateau. The highest degree of similarity between the myriapod communities has been reported the in park Kyoshkovete and the Bukaka reserve.
ACKNOWLEDGEMENTS. This paper is financially supported by the projects BG051PO001-3.3.06-0003 "Building and steady development of $\mathrm{PhD}$ students, post-PhD and young scientists in the areas of the natural, technical and mathematical sciences" and RD 08-213/2014, funded by Konstantin Preslavsky University of Shumen.

\section{References}

Anderson G. 1983. The chilopod fauna in the vicinity of Göteborg - a comparison between collecting results obtained in the 1920s and the 1970s years // Acta Ent. Fenn. Vol.42 P.9-14.

Andreev N. 1992. [Botanical characteristics of Shumensko Plateau Nature Park // Nature Park Shumensko Plateau]. A report, Agrolesproekt. P.17-62 [in Bulgarian].

Baars M.A. 1979. Catches in pitfall traps in relation to mean densities of Carabid beetles // Oecologia Vol.41. P.25-46.

Bachvarova D. 2011. Myriapoda (Chilopoda, Diplopoda) of Shumen City and Shumen Plateau (NE Bulgaria): Taxonomic Structure and Zoogeographical Analysis // Acta zool. bulg. Vol.63. No.3. P. 245-262.

Bonato L., Minelli A. 2014. Chilopoda Geophilomorpha of Europe: a revised list of species, with taxonomic and nomenclatorial notes // Zootaxa. Vol.3770. No.1. P.1-136.

Chudzicka E., Skibinska E. 1998a. Diversity of reactions insect communities as a response to anthropogenic pressure // Memorabilia zool. Vol.51. P.13-30.

Chudzicka E., Skibinska E. 1998b. Monitoring and role of terrestrial invertebrates in biondicatory evaluation of environment and changes // Memorabilia zool. Vol.51. P.3-12.

Czechowski W. 1982. Occurance of Carabids (Coleoptera, Carabidae) in the urban green of Warsaw according to the land 
utilization and cultivation // Memorabilia zool. Vol.39. P.3108.

Davis B.N.K. 1979. The ground arthropods of London gardens // London Naturalis. Vol.58. P.15-24.

Dunger W. 1958. Über die Zersetzung der Laubstreu durch die Boden-Makrofauna im Auenwald // Zool. Jahrb., Abt. Syst. Bd.86. H.1-2. S.129-180.

Enghoff H. 1973. Diplopoda and Chilopoda from suburban localities around Copenhagen // Vidensk. Meddr. Dansk. naturh. Foren. Vol.136. P.43-48.

Frund H.Ch. 1987. Raumliche Verteilung und Koexistenz der Chilopoden in cinema Buchn-Altbestand // Pedobiologia. Vol.30. P.19-29.

Frund H.Ch. 1989. Untersuchungen zur Biologie städtischer Boden. 5. Epigäische Raubarthropoden // Verh. Ges. Okol. Bd.18. S.201-209.

Gorgievska A., Prelit' D., Hristovski S., Stoev P. 2008. Spatial variation of myriapods along an Urban-Rural gradient in Skopje City and its surroundings // Ekologija i zaštita na životnata sredina (Skopje) Vol.11. No.1/2. P.43-54.

Hammer Ø., Harper D.A.T., Ryan P.D. 2001. PAST: Paleontological statistics software package for education and data analysis // Palaeontologia Electronica Vol.4. No.1. P.1-9.

Kasprzak K. 1981. Enchytraeids (Oligochaeta, Enchytraeidae) of Warsaw and Mazovia // Memorabilia zoologica. Vol.34. P.59-67.

Kuhnelt W. 1989. Characteristic and development of urban soil fauna // Int. Scient. Workshop on soil and soil zoology in urban ecosystems as a basis for management and use of green/open spaces. German Nat. Committee ed. UNESCO, MaB Mitteil. Vol.30. P.57-70.

Leśniewska M. 1996. Centipedes of Poznań town (Poland) // Geoffroy J.J., Mauriés J.P., Nguyen Duy-Jacquemin M. (eds.). Acta Myriapodologica. Mém. Mus. Natn. Hist. Nat. Vol.169. P.221224.

McDonnell M., Steward T.A., Pickett S.T.A., Pouyat R.V. 1993. The Applications of the Ecologycal Gradient Paradigm to the Study of Urban Effects // McDonnell M., S. Pickett T.A. (eds.) Humans as Components of Ecosystems: Subtle Human Effects and the Ecology of Populated Aries. New York: SpringlerVerlag. P.175-189.

McDonnell M., Pickett S.T.A., Pouyat R.V., Zipperer W.C. 1996. Urban-Rural Ecologycal Gradients: A new Perspective for Urban Forestry // Proceedings of the 7th National Urban Forest Conference. P.22-24.

Niedbala W., Blaszak C., Bloszyk J., Kaliszewski M., Kazmierski A. 1982. Soils mites (Acari) of Warsaw and Mazovia // Memorabilia zool. Vol.36. P.235-252.

Odum E.P. 1971. Fundamentals of Ecology. Philadelphia - London - Toronto: W.B. Saunders Company. 574 p.

Pisarski B. 1982. Ants (Hymenoptera, Formicoidea) of Warsaw and Mazovia // Memorabilia zool. Vol.36. P.73-90.

Pouyat R.V., Parmelee R.W., Carreiro M.M. 1994. Environmental effects of forest soil-invertebrate and fungal densities in oak stands along an urban-rural land use gradien // Pedobiologia Vol.38. P.385-399.

Pouyat R.V., McDonnell M., Pickett S.T.A. 1995. Soil Characteristics of Oak Stands along an Urban-Rural Land-Use Gradient // Journal Environmental Quality. Vol.24. P.516-526.
Sawoniewicz J. 1982. Ichneumonidae (Hymenoptera) of Warsaw and Mazovia // Memorabilia zool. Vol.36. P.5-39.

Sawoniewicz J. 1986. Structure of Ichneumonidae (Hymenoptera) communities in the urban green areas of Warsaw // Memorabilia zool. Vol.41. P.103-124.

Schulte W., Frunda H.Ch., Sontgen M., Graeff U., Ruszkowski B., Voggenreiter V. 1989. Untersuchungen zur bodenokologischen Bedeutung von Freiflachen im Stadibereich. Hamburg: Forschungsbericht des Bundesministerium für Forschung und Technologie.

Skibinska E. 1978. Influence de la pression urbaine sur les Groupements de Vespidae // Memorabilia zool. Vol.29. P.173-181.

Skibinska E. 1982. Sphecidae (Hymenoptera) of Warsaw and Mazovia // Memorabilia zool. Vol.36. P.103-127.

Skibinska E. 1986. Effect of anthropogenic pressure on Vespoidea and Sphecidae communities // Memorabilia zool. Vol.42. P.55-66.

Striganova B.R. 1969. [Distribution of Diplopoda in mixed forests of the northern Caucasus and their role in the destruction of forest litter] // Zoologicheskij zhurnal. T.48. No.11. P.16231628 [in Russian].

Striganova B.R. 1974. [Distribution of Diplopoda in the Carpathian USSR foothills and their role in the decomposition of forest fall] // Zoologicheskij zhurnal. T.53. No.9. P.1308-1314 [in Russian].

Stoev P. 2002. A Catalogue and Key to the centipedes (Chilopoda) of Bulgaria. Sofia-Moscow: Pensoft. 103 p.

Stoev P. 2004. Myriapoda (Chilopoda, Diplopoda) in urban environments in the City of Sofia // Penev L., Niemelä D.J., Kotze D., Chipev N. (eds.). Ecology of the City of Sofia. Species and Communities in Urban Environment. Sofia-Moscow: Pensoft. P.299-306.

Trojan P. 1994. The shaping of the diversity of infertebrate species in the urban green spaces of Warsaw // Memorabilia zool. Vol.49. P.167-173.

Tzonev R., Dimitrov M., Chytry M., Roussakova V., Dimova D., Gussev C., Pavlov D., Vulchev V., Vitkova A., Grogushev G., Nikolov I., Borisova D., Geva A. 2006. Beech forest communities in Bulgaria // Phytocoenologia. Vol.36. No.2. P.247-279.

Vepsäläinen K., Wuorenrinne H. 1978. Ecological effects of urbanization on the mound-building Formica L. species // Memorabilia zool. Vol.29. P.191-202.

Winiarska G. 1986. Noctuid moth (Lepidoptera, Noctuidae) communities in urban parks of Warsaw // Memorabilia zool. Vol.42. P.125-148.

Wytwer J. 1995. Faunistical relationships between Chilopoda of forest and urban habitats in Mazowia // Fragm. faun. T.38. No.2. P.87-133.

Zapparoli M. 1992. Centipedes in urban environments: record from the city Rome (Italy) // Ber. nat. med. Verein Innsbruck. Suppl.10. P.231-236.

Zapparoli M. 1999. The present knowledge of the centipede fauna of Anatolia (Chilopoda) // Biogeographia. Vol.20. P.105-177.

Zapparoli M. 2002. A catalogue of the centipedes of Greece (Chilopoda) // Fragmenta Entomologica. Vol.34. No.1. P.1146.

Responsible editor S.I. Golovatch 